\title{
RESEARCH AS INTERVENTION WITHIN COMMUNITY MENTAL HEALTH
}

\section{MACLEOD}

\section{ABSTRACT}

This paper raises some issues for discussion and debate concerming the nature of research within a mental health setting. Research, no matter what form it takes, is always an intervention. Sensitivity to various concerns surrounding research is required of the mental health worker. Participatory research, which is seen as empowering participants, has become popular in mental health programmes. Attention needs to be paid, however, to the meaning of participation and the process of decision-making. Researchers are often uncomfortable with shedding their "objective informer" stance and adopting a position that requires social action. Some of this has to do with the epistemological view taken by the researcher. This paper suggests that the knowledge produced in research is a social construction created in interaction between the researcher and participants and has a multiplicity of potential meanings. The instnomental, conceptual and persuasive uses of research are discussed, and two intervention-tvpe research procedures (needs assessment and evaluation) are critically reviewed. It is concluded that research, as with all other interventions, should be carefully planned, implemented, monitored and evaluated.

\section{OPSOMMING}

Hierdie artikel bring sekere aspekte met betrekking tot navorsing in ' $n$ geestegesondheidsopset na vore vir bespreking en debattering. Navorsing, van enige aard, is altyd ' $n$ intervensie. Sensitiwiteit ten opsigte van sekere aangeleenthede in die navorsingsopset word vanaf die geestegesondheidswerker verlang. Deelnemende novorsing, wat beskou word as ' $n$ wyse om deelnemers te bemagtig, het algemeen in geestegesondsheidsprogramme geword. Aandag moet egter verleen word aan die betekenis van "deelname" en die besluitnemingsproses. Navorsers voel dikwels ongemaklik om hulle "objektiewe bystander" posisie te verruil vir een wat sosiale aksie verg. Dit het gedeeltelik te make met die epistemologiese oortuiging van die navorser. Die aanduiding uit hierdie artikel is dat die kennis wat deur novorsing geproduseer 'n sosiale konstruksie is wat geskep is uit die interaksie tussen die navorsers en die deelnamers vanaf ' $n$ verskeidenheid van potensiele betekenisse. Die instrumentele, konseptuele en oorredende gebruike van navorsing word bespreek, en twee intervensie-tipe navorsingsprosedures (behoefte beraming and evaluering) work krities betrag. Die gevolgtrekking word gemaak dat navorsing, soos alle andere intervensies, deeglik beplan, geimplementeer, gemonitor en geevalueer behoort te word.

settings. Some of the concerns, conflicts and problems that may arise in such research are elucidated. Research methodology is not discussed but some issues for discussion and debate are raised.

The paper is divided into various sections. The first two of these are fundamental to the research process, whatever form it takes. These are : (1) the relationship between the researcher and the research participants, and (2) the approach adopted by the researchers to research and its uses. The following two sections deal with specific intervention-type research procedures that may be used by community mental health workers. These are: (1) needs assessments, and (2) evaluation. The final section focuses on the most neglected aspects of the research process viz. the feedback of research results to research participants.

\author{
THE RELATIONSHIP BETWEEN THE \\ RESEARCHER AND THE RESEARCH \\ PARTICIPANTS
}

The traditional research relationship is a hierarchical one, in which the researcher controls the process completely, and is viewed as the "objective outsider", studying the "reality" out there. By contrast, community psychology has attempted in many instances to conduct research in a participatory manner. From this perspective, the research relationship is grounded in bilateral exchange. Research is essentially seen as an interpersonal process.

Participatory research is becoming more and more popular in a variety of fields - Participatory Rural Appraisal (PRA) in development work is a prime example (see Chambers, 1985). Various mental health workers in South Africa have begun to use this approach as well. Van Vlaenderen (1993) provides an excellent review of participatory psychological research in South Africa. However, much of the literature and work on participatory research is unreflective on a number of issues. The first of these is the definition of participation; the second is the issue of power within the research relationship.

Authors often do not define what they mean by participation in their reports. They treat the word as unproblematically unitary in meaning. Those who do define it differ in the degree of value they place on the end-product of the process. For example, Katzenellenbogen, Pick, Hoffman \& Weir (1988:335) define participation in the Mamre Health Project in South Africa as "the process whereby people are involved with, and share in, a variety of activities with a communal goal". This definition remains neutral (whether intentionally or not is not clear) by not ascribing any value (good or bad) to the communal goal. Bjärås (1991:191), on the other hand, saw participation in an accident prevention programme in Sweden as "a social process of taking part in either formal or informal activities, programmes and/or discussions to bring about a planned change or improvement in community life, services and/or resources" (my emphasis). In this definition the goal is to move towards something better rather than just to move (although there is no indication of whose definition of "improvement" would be used).

It will be noticed that neither of the above definitions tackle the issue of decision-making. Decision-making is directly related to the issue of power within the research relationship. There
In this article research is looked at as intervention in community mental health 
are two important facets concerning power: the ownership of the means of knowledge production, and the status roles of the researcher vis-a-vis the participants. Participation in the planning of the research and feedback of research results are attempts to share ownership of knowledge, and thus may be seen as processes which create a more egalitarian relationship between researcher and participants than is common in the traditional relationship. However, ever-lurking behind this is the mode of knowledge production which falls directly into the hands of the researcher. The researcher has overall understanding and ultimate control of the research process and is familiar with the type of abstract thinking required in the research endeavour (Jackson \& Van Vlaenderen, 1994). Furthermore, researchers generally hold higher status roles than the participants (Walsh, 1987). This usually includes social or class status as well as the positioning of the researcher as scientist-professional

It is important therefore to recognise that the research relationship will never be completely horizontal. This realisation puts the researcher using participatory methods in a difficult position as it seems, at first reading, to be contradictory to the tenets of participation. However, the ideal must be separated from the real. Instead of wishing for an egalitarian relationship and assuming that this is achieved through the involvement of the research participants, the researcher should rather reflect on the power dynamics that are present in the relationship. Being aware of these dynamics and making them explicit is more beneficial to the process than allowing unconscious or implicit power differentials. The latter risks paternalism and dependency.

\section{THE APPROACH ADOPTED TO RESEARCH AND ITS USES}

"The tendency of .. researchers to adopt naïve and positivistic methodological approaches in the study of psychological phenomena inevitably serves to legitimize and perpetuate racist social arrangements which are not conducive to sound mental health for all" (Mkhize, 1994:194).

There has been much writing in the mental health literature such as the above criticising the premises of positivistic research. And yet, even within fields such as community mental health, there seems to be an inability to throw off the mantel provided by the parent discipline (Walsh, 1987). There is an uncomfortableness in moving beyond the traditional requirements of scientific rigour, and moving into a domain which requires social action and involvement on the part of the researcher (Seidman, 1988), a domain which many consider essential for effective community practice.

The "objective informer" stance of traditional research is based on the assumption that social scientists practise value-free science, and that knowledge is a static entity waiting to be discovered. But research is a creation and endeavour of human beings and is thus unable to transcend human biases. The knowledge produced in research is a social construction, created in the interaction between researcher and participants from a multiplicity of potential meanings. Lincoln (1992), in her article on health promotion research, illustrates this well by drawing a distinction between what she calls constructuctivist research and conventional research. In the constructivist model the questions that are asked are ontological (What is there that can be known? What is the form and nature of reality?), epistemological (What is the relationship between the knower and the knowable?), and methodological (How can the inquirer go about finding out the knowable?). In conventional research the first two of these questions are essentially ignored. Lincoln (1992) sees constructivist research as hermeneutic, expansionist, nondeterministic and revelatory.

Research participants should thus be seen "as agents of and not as victims of knowledge" (Jackson \& van Vlaenderen, 1994:9). They are co-producers of the knowledge generated in research. From this position the researcher is unable to assume that $\mathrm{s} /$ he operates outside of the process, but is aware, as Wilkinson $(1986: 13)$ puts it, that the "knower is part of the matrix of what is known". This implies that the processes followed in community mental health research will include elements such as: (1) moving away from referring to research participants as "subjects"; (2) paying careful attention to issues of informed consent and gaining entry into the research setting; (3) active participation of all stakeholders in the complete research process; (4) provision of feedback on findings in an accessible form; (5) co-operative use of the data for planning and development.

Moving beyond the traditional approach to research does not mean abandoning rigour. Indeed, research which recognises the participation of people in the construction of knowledge can claim greater ecological and face validity. Experimental rigour is replaced by "inter-subjectivity" rigour (where there is a shared agreement of meaning) (Van Vlaenderen, 1993), and judgements of credibility, transferability, dependability, and authenticity (Lincoln, 1992). Furthermore, performing community-based research does not mean abandoning quantitative research in favour of qualitative research. As Sechrest \& Figueredo (1993) argue, the issue should not be framed in an absolute either/or dichotomy. The distinction should rather be made between exploratory and confirmatory research (for example, between needs assessment and evaluation), as these represent two complementary, sequential stages of the process, rather than alternative procedures. Lincoln (1992) believes that it is not a change to qualitative research that is needed, but rather a shift in paradigmatic assumptions.

We turn to the uses to which research may be put. Shadish (1990) identifies three potential uses: instrumental, conceptual and persuasive. Instrumental use is where results dictate direct changes in programmes; conceptual use aims to change the way people think about problems and their solutions; persuasive use means gathering sufficient evidence to support a particular position or to influence policy. The first question which the researcher has to reflect upon is to which uses s/he intends to put the research, and why. But the thinking should not stop here, as the participants, as co-owners of the results, may foresee different uses. Negotiation needs to be engaged in around this issue. The second question relates to the processes which need to be engaged in in order to facilitate the intended use of the research results. Examples include: feedback of research results to participants; advocacy documents intended for relevant agencies, local, regional or national authorities; mass media reports; academic articles; and training manuals.

In the next section I review two intervention-type research procedures frequently engaged in by community mental health workers: needs assessment and evaluation. Some issues for discussion are raised in each.

\section{NEEDS ASSESSMENT}

In the United States federal requirements for programmes to assess "need" began to appear in legislation in the mid-sixties (Kimmel, 1979) as a result of increasing pressure for cost reduction and accountability, and a demand for the justification of activities. It is becoming popular in South Africa to see needs assessment as a logical first step in developing programmes. Reasons for conducting needs assessments include programme planning, grassroots input into policy and programme decisions, using results for advocacy purposes, and ensuring participatory decision-making concerning programmes. However, there are many pitfalls associated with needs assessments that should be carefully considered before the process is embarked upon

Very often needs assessments are conducted within a theoretical vacuum. Because the activity is one that did not arise within any one particular discipline, it lacks a conceptual and theoretical grounding. Before embarking on a needs assessment the research team should make explicit the theoretical paradigm from which they will be working. They should also examine the meaning of each of the words "needs" and " assessment".

Tuming first to the notion of "need". There have been various conceptualisations of the word. These can be broadly classified as: basic human needs; comparative needs; normative needs; felt or expressed needs (Monette, 1984). Basic human needs refer to a deficient state that initiates gratification-seeking behaviour on the part of the individual. Comparative needs involve comparing the characteristics of those who "have" and those who "do not have". Normative needs are described as the gap between what exists and the desirable situation. The norm is usually identified by experts using a standardised yardstick (e.g. standards of 
mental health care as defined by the World Health Organisation). Felt needs are those expressed through action or statement by an individual, group or organisation.

Each of the categories of "need" identified involves the play of values. Even to say that food is a basic human need is to hold the value that people should not starve. Using comparative needs involves some decision-maker judging the desirability of the characteristics of those defined as "having". Again, within normative needs, the value of the norm is not questioned. Felt needs are those which most openly embrace the notion that needs are not value-free. Distinction is not made between "felt" and "real" needs (who decides on the real needs?). Advocates of this approach believe that felt needs should be utilised as a motivation to action and a tool of empowerment towards the transformation of people's social reality (lutcovich, 1993).

Let us look at the word "assessment'. It could refer to: the collection of numerical data, the description of a scene, an analytical procedure, adecision-making process, or a procedure aimed at change (Kimmel, 1979). The researcher needs to be aware of all of these possible interpretations of the word and to be explicit at to what she sees as the process of assessment.

There is no one single or preferred method for embarking upon a needs assessment. A reading of the literature will indicate that there are many, heterogeneous methods, such as: interviews with key informants, focussed discussions with community groupings, the gathering of service statistics, epidemiological studies, surveys, incidence and prevalence studies, use of social indicators, or any combination of the above (Kimmel, 1979). The method decided upon must link conceptually with the researchers' understanding of the word "need". Furthermore, assessing needs alone is insufficient; there should be a resource or service analysis that accompanies the assessment (De Villaer, 1990).

The process followed differs considerably, according to the purpose of the assessment. Some authors (e.g. Kaufman, 1987; McClelland, 1992) provide steps that the researcher can follow. Innes \& Heflinger (1989) propose the following flexible, participatory procedure: (1) Define the parameters of the project and the constituent groups (people likely to be affected by the project, or "stakeholders") involved; (2) Identify common values among the constituent groups as well as their information needs; (3) Integrate and translate existing research knowledge (for example literature reviews); (4) Develop procedures for gathering information; (5) Gather and organise community level information; (6) Present information to constituency groups. The authors present a case study of a day care centre to illustrate the process.

Another issue that must be carefully thought through by researchers is the target population of the research. This essentially boils down to the question of "What is community?' There is extensive literature and debate on this issue (see, for example, Dunham, 1986; Hunter \& Riger, 1986; Isemonger, 1990). Space does not allow for a full discussion thereof here. However, it is important that researchers are aware of the various possible boundaries that they are putting on the meaning of "community", and the implications that this will have theoretically and practically in their work.

\section{PROGRAMME EVALUATION}

The evaluation of programmes is closely linked to the notion of accountability. Is the programme having the effects that it is supposed to be having? Is it doing so in a cost-effective manner? What are the elements that can be improved? Researchers may find themselves having to be accountable to a number of groupings, including agencies, funders, community stakeholders, universities etc. There may be a clash of interests between these various sets of interested parties, and the researchers may find themselves having to step a fine line.

The type of evaluation embarked upon depends on the reason for the evaluation, and the questions asked. Classically, evaluation is divided into two types: formative or process evaluation, and summative or outcome evaluation. Ideally formative evaluation occurs towards the beginning of the programme, and summative later (Grasso \& Epstein, 1992).

Formative evaluation guides programme development so as to produce the best version possible of the intervention. It is developmental in emphasis, using information for generating programme innovation and change. It is an inductive, programme-based theoretical approach that is concerned with modifying and improving programme efforts, effectiveness and efficiency (Sechrest \& Figueredo, 1993).

Summative evaluation is designed to determine whether the programme had effects commensurate with the original goals and with the costs and efforts required to produce the intervention. It relies on retrospective findings that test deductive hypotheses about programme interventions and outcomes and yields findings that can be generalised to other comparable programmes. Summative evaluation is, however, hard to do, as determining whether programmes work requires supporting a causal inference. A strong research design is thus required with careful attention to sample size, statistical techniques utilised etc. Furthermore it requires a commitment to a considerable period of time and to the evaluation itself (Sechrest \& Figueredo, 1993).

Thus we see that summative evaluation calls into question the very reason for the existence of the programme or organisation whereas formative evaluation only asks "how can we do better?". Summative evaluation also requires an "objective" stance to be taken, a position most community mental health workers using participatory methods would feel uncomfortable assuming. However, summative evaluations are at times demanded by funders of programmes, to whom the mental health worker is also accountable.

\section{FEEDBACK OF RESEARCH RESULTS}

Once research is completed there are various channels through which the results may be made available for public consumption. These include: policy statements (directed at agencies, government etc.), scholarly articles (for reading by fellow researchers or academics), mass media (to reach a wide spectrum of "lay" people); inclusion in student curricula; feedback of research results to the research participants and immediate community. It is on the last of these that is the focus in this section.

Feedback to the participants of research is an aspect of the research endeavour which is largely ignored, or treated as unproblematic. For example in a literature review of the American Joumal of Community Psychology and the Journal of Community Psychology, Walsh (1987) found that the overwhelming majority of studies made no mention of feedback. He suggests, however, that researchers may have paid more attention to issues around community participation and feedback than is suggested in their published reports. McConnell \& Kerbs (1993) (who also state that there is a dearth of literature which discusses feedback to participants) dispute this. They studied the degree to which feedback was provided by researchers in a division of a metropolitan health department in the United States. It was found that feedback was done in approximately $30 \%$ of cases and that there was a higher rate of provision of a progress report to the agency, than of other feedback. This lack of feedback has been a feature in the South African research world as well, where research has in the past often been used either for the academic advancement of the researcher only, or as justification for the implementation of unpopular development policies under the apartheid government (Van Vlaenderen, 1993).

Various guidelines, or factors that could influence the utilization of feedback material have been identified in the literature (Altschuld, Yoon \& Cullen, 1993; Barton, Smith, Brown \& Supples, 1993; Fawcett, 1991; Innes \& Heflinger, 1989). These include: presenting the results in such a way that they are accessible and relevant to the audience; framing the results so as to limit their potential to blame unempowered people for their problems; communicating results openly, even when some of the stakeholders may not benefit from such open communication; allowing for information flow from the relevant audience to the presenter, thus ensuring that the participants' perspective on what is important in the research is heard; establishing and maintaining the credibility of the person who has conducted the research; seeing feedback as an ongoing process of dialogue and discussion with key stakeholders; having a written report available at the time of the oral presentation; timing the feedback 
session correctly; being aware of the political considerations behind the research and the feedback; keeping the communications as jargon-free as possible, even with relatively well-trained audiences; conducting an evaluation of the validity of the findings at the time of the oral presentation; having a representative from the project assist in the development of a task force of community members to study the recommendations.

Low attendance at presentations may present a problem. Barton et al (1993) suggest that attendance is not always related to the amount of media coverage and number of reminders sent concerning the presentation. In their experience, attendance is higher if the project has been strongly supported by a well-known community group. Bjärås (1991) reminds us, though, that participation cannot simply be quantified by the number of people who attend meetings (although this is a common way of measuring programme success). "Head counts" should be augmented by qualitative evaluations of the participative process.

Disagreement conceming the data and the interpretation thereof may occur in the feedback sessions. Community members may disagree with the researcher(s) or community members may disagree amongst themselves. Barton et al (1993) suggest that such disagreement represents different vested interest groups. In order to avoid this they suggest the following strategies: making sure that the "sample" is representative of all groups within a community, and including community members as part of the team to ensure "authenticity" of the interpretations. This approach, however, assumes that there is an "authentic" or correct way to interpret data. I would suggest, however, that differences in interpretation are inevitable as knowledge is constructed from a multiple of potential meanings. Levine \& Perkins (1987) agree and argue that there should be a recognition of paradox and multiplicity in the process of meaning negotiation; they believe that growth can occur through this.

Feedback of research results is seen by many researchers as an important aspect in effecting social changes in a community as the information may be used to support group action (Walsh, 1987). However, this view of feedback may be more idealistic in many circumstances, than real. In South Africa, for example, the historical background of unequal education and ideological propaganda by the ex-Nationalist government means that communities often lack the skills or the procedural know-how to use research results. Certainly, there is little literature that describes group action utilization of research data. Smail (1994) takes a less idealistic view of feedback. He believes that research results should be supplied to communities for them to use as they see fit, but adds: "It might, of course, be that people are unimpressed by both our knowledge and our methods -which they would be entirely entitled to be - but at least they wouldn't be in the dark about what we get up to." (p. 8).

\section{CONCLUSION}

In this article I have attempted to raise some issues conceming research from a community mental health perspective. Some problems associated with needs assessments, evaluations and the feedback of research results have been raised. What I have tried to illustrate in the main is that the community mental health worker, in his/her research, moves beyond the constraints of traditional research methodology, approach and process. S/he views research as a bilateral exchange, in which knowledge is socially constructed from a multiplicity of potential meanings. In making this shift the community mental health worker may find him/herself in a domain in which there are more questions than answers, more disputes and uncertainties than absolutes. This is the nature of community work, and in order to navigate the process successfully, the mental health worker will have to adopt a reflexive approach to his/her research. This involves constantly asking questions of various types, including those surrounding epistemology, ontology, methodology and process. The researcher needs to reflect on issues such as: the relationship between the participants, research team, funders, and agencies; the theoretical backdrop of the research, and the approach taken by the research team; the purposes for which the research will be used; the degree of participation of community members etc.

Research is one of the most powerful tools the community mental health worker has at his/her disposal. These skills should be used to the benefit of the community within which $s /$ he is working. Research is from the outset intervention, and should be carefully planned implemented, monitored and evaluated, as with all other interventions.

\section{REFERENCES}

Altschuld, J.W., Yoon, J. S. \& Cullen, C. (1993). The utilization of needs assessment results. Evaluation and Program Planning, 16 (4), 279-285.

Barton, J. A., Smith, M. C., Brown, N.J. \& Supples, J.M. (1993). Methodological issues in a team approach to community health needs assessment Nursing Outlook, 41, 253-261.

Bjärás, G. (1991). The need of leadership for motivation of participants in a community intervention programme. Scandinavian Journal of Social Medicine, 19 (3), 190-198

Chambers, R. (1985). Rural development. Putting the last first. London: Longman.

De Villaer,M. (1990). Client-centre community needs assessment. Evaluation and Program Planning, 13 , 211-219.

Fawcett. S.B. (1991), Some values guiding community research and action. Journal of Applied Behavior Analysis, 24 (4), 621-636

Innes, R.B. \& Heflinger, C.A. (1989). An expanded model of community assessment: A case study. Journal of Community Psychology, 17 (3), 225-234.
Iutcovich, J.M. (1993). Assessing the needs of rural elderly: An empowerment model. Evaluation and Program Planning, 16,95-107.

Jackson, C.A. \& Van Vlaenderen, H. (1994), Participatory research: A feminist critique. Psychology in society, 18, 3-20.

Katzenellenbogen, J.M., Pick, W.M., Hoffman, M. \& Weir, G. (1988). Community participation in the Mamre community health project. South African Medical Journal, 74 (7), 335-338.

Kimmel, W.A. (1979). Needs assessment: A critical perspective. Social Work, 10, 289-304.

Lincoln, Y.S. (1992). Sympathetic connections between qualitative methods and health research. Qualitative Health Research, 2 (4), 375-391.

McClelland, S. (1992). A systems approach to needs assessment. Training and Development, 46 (8), 51-53.

Mkhize, H. (1994). Violent oppression: Implications for mental health priorities in South Africa. Medicine and Law, 13 (1-2), 193-203.

Monette, M.L. (1984). The concept of educational need: An analysis of selected literature. In S.B. Merriam (ed.) Selected writings on philosophy and adult education. Florida: Krieger.

Sechrest, L. \& Figueredo, A.J. (1993). Program evaluation. American Review of Psychology, 44 645-674.

Seidman, E. (1988). Back to the future, community psychology: Unfolding a theory of social intervention. American Journal of Community Psychology, 16 (1), 3-24.

Shadish, W.R. (1990). Defining excellence criteria in community research. In P. Tolan, C. Keys, F. Chertok \& L. Jason (eds), Researching community psychology: Issues of theory and methods (pp. 9-20). American Psychological Association Washington DC.

Van Vlaenderen, H. (1993). Psychological research in the process of social change: A contribution to community development. Psychology and Developing Societies, 5 (1), 95-110.

Walsh, R.T. (1987). The evolution of the research relationship in community psychology. American Journal of Community Psychology, 15 (6), 773-788.

Wilkinson, S. (1986). Sighting possibilities: Diversity and commonality in ferninist research. In S. Wilkinson (Ed.) Feminist social psychology: Developing theory and practice (pp. 7-24). Milton Keynes: Open University Press.

Catriona Macleod M.Ed (Psych) Department of Educational Psychology UNIVERSITY OF ZULULAND 